\title{
Legal Consequences for Nominee Deed Notaries
}

\author{
Dita Perwitasari ${ }^{1 *}$, Maydinah Syandra Fairina ${ }^{2}$ \\ ${ }^{1}$ Universitas Negeri Surabaya \\ ${ }^{2}$ Universitas Negeri Surabaya
}

*Corresponding author.Email: ditaperwitasari@unesa.ac.id

\begin{abstract}
The Nominee Agreement in Indonesian civil law which is based on the Civil Code does not have any rules in it. An agreement that has no rules in the Civil Code can be called an anonymous agreement (Innominant Contract). Where this unnamed agreement is an agreement which rules are not yet contained in the Civil Code, but in fact exist and develop in society following the times. The writing of this journal article is normative juridical research using a statutory approach, a case approach, and a conceptual approach. This study was made to analyze and describe the legal consequences that will occur to the notary who makes the Nominee deed. It can be interpreted that a notary who makes an authentic deed in the form of a nominee deed will face the consequences of making the deed where it can be said that the nominee deed is a deed that leads to legal smuggling. Based on the explanation above, the results obtained from the research are that a notary can be subject to sanctions against the authentic deed he made. Because this is an act against the law both in civil, criminal, and in the form of administration.
\end{abstract}

\section{Keywords: Nominee Agreement, Legal Consequences, Notary.}

\section{INTRODUCTION}

Indonesia is a developing country which makes it a country with great investment potential. So that the state through its government provides "freedom" for investors who want to invest in Indonesia. However, the "freedom" in question is certainly not the widest, but there are limits that must be followed and obeyed by investors who will invest in Indonesia, especially foreign investors. Investment is not always in the form of money, meaning "fresh money", but can also be in the form of assets, for example with fixed objects, namely land. Regarding land in Indonesia, it has a national land law regulation, namely Law Number 5 of 1960 concerning Basic Regulations on Agrarian Principles (Law No. 5 of 1960). In the national land law regulations, some regulations clearly prohibit foreign parties (in this case investors or capital owners) from being able to control land rights in the form of certificates, where the land rights in question are property rights, or if the form is a limited liability company, it is prohibited to have a certificate of ownership.

However, of all these provisions, legal smuggling is often carried out, namely by holding what is called the practice of "nominee" agreements. This is done where his party is a local citizen or Indonesian citizen (WNI) whose name is "borrowed" by binding through an underhand agreement, in which it is said that the local citizen or Indonesian citizen who "borrowed" his name will acknowledge and state that the land object referred to in the agreement is the property of the financier or investor (foreigner or Persero company), even though later on the proof of rights listed is in the name of the local citizen/WNI. Thus, it can be said that the "nominee" agreement is against the law or contrary to the law. Because there is smuggling or legal irregularities that occur.

Because the "nominee" agreement is an agreement that is against the law, the "nominee" agreement can be categorized as an agreement containing "illegal causes". So it can also be said that this agreement does not fulfill the "objective element in the legal terms of the agreement" which is stipulated in Article 1320 of the Civil Code (KUHPerdata), which of course results in the "nominee" agreement being null and void from the start of the agreement. /made by the financier (investor) and local residents /WNI.

A Notary as an Official, in this case, is the party authorized to make a deed and has other authorities in accordance with the laws and regulations in Indonesia, especially the Notary Position Act. This is based on Article 1 of Law Number 30 of 2004 concerning the 
Position of Notary Jo. Law Number 2 of 2014 concerning Amendments to Law Number 30 of 2004 concerning the Position of Notary (hereinafter referred to as UUJN). The authority referred to above is emphasized in Article 15 paragraph (3) of the UUJN which states: "Notaries make authentic deeds regarding all acts, agreements, and stipulations required by laws and regulations and/or determined by the interested parties to be stated in an authentic deed. guaranteeing the certainty of making the deed, keeping the deed, giving the grosse, date, and quotation of the deed, all as long as the making of the deed is also not assigned or excluded to other officials or other people stipulated by law [1]. The developments in the notarial world are also in line with the times, and of course, the business and business world continue to grow and advance, sometimes even leaving the legal regulations that govern it.

This can be seen from the development of businesses and business fields in Indonesia. Indonesia as a country that is rich in natural wealth and also has various natural resources, of course there are also human resources who live there. For example, in the case of land ownership in Indonesia, based on the national land law regulations, namely the Basic Agrarian Law Number 5 of 1960, that a plot of land owned can only be owned by Indonesian citizens, with the exception of legal entities, which of course the arrangement already exists. and promulgated (Article 21 paragraph 1 and Article 21 paragraph 2 of the Basic Agrarian Law) [2]. As mentioned in the Basic Agrarian Law as well as in the provisions of the Nationality Principle contained in the General Elucidation of the Basic Agrarian Law Number 5 of 1960 concerning Basic Agrarian Basic Regulations (UUPA) that the Nationality Principle is a principle that provides limitations in ownership of rights to land. land which then results in different treatment of land objects and non-land objects.

Then there are also arrangements for foreign investors (investors) in Article 5 paragraph (2) of the Investment Law, Law Number 5 of 2007 which stipulates that, unless otherwise regulated, foreign investors can carry out foreign investments in Indonesia by establishing foreign investment companies based on Law no. 40 of 2007 concerning Limited Liability Companies and its implementing regulations [3]. Foreign investment companies are also in this case also referred to as PT (Limited Companies (Persero)) Foreign Investments. Foreign investment in Indonesia in the form of a Limited Liability Company can be carried out with share ownership carried out at the time of the company's establishment or purchase of shares in the company that has been established. Either in the form of a domestic Persero or a Foreign Investment Company (PT PMA), but of course, you must complete the licensing documents for the requirements for the establishment of the company. These requirements are legally a special concern for foreign investors in Indonesia before carrying out their investment activities in the country.

Law Number 25 of 2007 concerning Investment also prohibits the practice of nominees for share ownership. Because it is an act that clearly violates the applicable rules. It can be said because this is happening in Indonesia where foreign nationals or foreigners are not allowed to invest or invest in a closed line of business. Therefore, because of the existence of restrictions and the difficulty of the requirements that have been regulated by the government for these foreigners, it makes the parties who are certainly interested in finding ways to have more land than the Right to Use. Where the right of use is the right given by the government to foreigners. While the right of ownership is the right that is given to be more flexible in using the land because the right of ownership is the highest, strongest and hereditary right, to share ownership so that they can continue to invest in Indonesia against closed companies. . Foreign investors of course want property rights too.

Finally, the method used to meet the business needs of foreign investors is to make a Nominee Deed between Foreign Citizens (WNA)/Foreigners and Indonesian Citizens (WNI), namely by using the name of another person who is an Indonesian citizen as appointed as a Nominee. to be registered as the owner of the land. The Nominee Agreement which is stated in the nominee deed in contract law in Indonesia can be categorized as an agreement with the indication of creating legal smuggling. As previously explained. Of course this raises a problem where what is the result of making this nominee deed against a notary, as a public official who makes the deed.

\section{METHODS}

According to Peter Mahmud Marzuki, legal research is a process to find the rule of law, legal principles, and legal doctrines in order to answer the legal issues faced [4]. This study uses a normative juridical research methodology, namely legal research that is based on or refers to the legal rules or norms contained in the legislation [5]. According to Soerjono Soekanto, the normative approach is legal research carried out by examining library materials or secondary data as the basic material to be researched by searching for regulations and literature related to the problems studied [6].

This study uses a statute approach, a conceptual approach, and a case approach. Legal materials consist of primary legal materials and secondary legal materials. The primary legal materials used include the 1945 Constitution of the Republic of Indonesia, the Civil Code, Law Number 5 of 1960, Law Number 25 of 2007. Secondary legal materials are obtained through scientific works in the form of journals, books, theses containing 
relevant doctrines and concepts. The technique of collecting legal materials on primary legal materials is carried out by using a statute approach and a case approach. Meanwhile, secondary legal materials were collected using a conceptual approach with library research and searching through the internet.

\section{RESULTS AND DISCUSSION}

This nominee agreement or borrowing name does not have any regulations in the Civil Code. However, in reality, this is growing and developing in society. This agreement also falls into the category of an anonymous agreement or an in nominaat agreement. The nominee agreement has a fairly broad scope in terms of its validity wherein the nominee deed itself there is a causa for power of attorney. The Nominee Agreement can be said to be a simulation agreement [7] (fake agreement, borrowing name) which of course was carried out by several parties, namely where it seemed as if an agreement had occurred, but secretly the parties agreed that the agreement was not valid. Definition of Nominee in the legal dictionary or Black's Law Dictionary [8], is: a person is appointed to act on behalf of another party as a representative in a limited sense. It is used from time to time to be signed by an agent or confidant. This can happen in a legal relationship between the parties where there is no action or with a simulation agreement or borrowing a name, other things will apply. So, there is no conflict between the will of the parties and the reality. Thus, the agreement can be null and void following what is contained in Article 1337 of the Civil Code [9], a prohibited cause and an aggrieved third party can cancel this.

In the practice of a Notary, some terms are similar to a nominee agreement, namely, CONTRA LETTER, NOMINEE/SCHIJNHANDELING/LOAN NAME, SIMULATION, PRETENDING AGREEMENT [10]. A nominee is a legal action that has been agreed upon by the parties or can be stated by one of the parties stating the truth behind the enactment of the legal action. For example, when a foreigner cannot own land rights in Indonesia, then borrow the name of the Indonesian citizen to buy the land. After that, the foreigner and the Indonesian citizen agreed to enter into an agreement stating that the land that had been purchased was purchased and owned by the foreigner, then added with other deeds or clauses used to protect the foreigner. Then the next step is where a foreigner borrows the name of an Indonesian citizen to establish a Limited Liability Company (PT). The Indonesian citizen is a shareholder in the relevant PT, then the Indonesian citizen declares the shares do not belong to him but belong to the foreigner. Another thing that also happens to Indonesian citizens themselves does not always happen to foreigners. When an Indonesian citizen buys property in large quantities, because he wants to avoid paying the annual tax imposed or because he personally owns land that has exceeded the land ownership limit, then the next land purchase is by borrowing the name of another person he knows to buy the property. Then another person he knew stated that the property he owned was not his, but only borrowed the name.

In practice in Indonesia, nominee agreements are included in the realm of land ownership and also for share ownership, investment, the establishment of PT, and all forms of ownership in civil law. The nominee agreement is stated in the form of a deed by the parties to be able to strengthen the agreement. The agreement is made in the form of an authentic deed. The Nominee deed made by a Notary, as a public official who is authorized to make an authentic deed can be said to be an unlawful act which is also committed by the parties contained in the deed because this act contains elements of violating public order. The unlawful act in question is in the form of legal smuggling. This action clearly violates the law and the provisions of the applicable law. It is very clear that the act is unlawful because it contains elements of an unlawful act contained in Article 1365 of the Civil Code.

That the Nominee/Borrowing Name (same as Contra Letter) can be equated as a Legal Smuggling Deed or Simulation (proforma). According to the Jurisprudence of the Supreme Court of the Republic of Indonesia Reg. $2510 \mathrm{~K} / \mathrm{Pdt} / 1991$ dated April 8, 1993 [11] it is stated if "A Notary who makes an authentic deed pretending (proforma) and the material is not in accordance with the actual reality (facts), even contrary to the material truth, then the notarial deed made in this way is invalid and has no legal force. from the date of issuance of the deed.

\subsection{Elements of Unlawful Acts (PMH)}

Article 1365 of the Civil Code (Kuhperdata) [9], It states that: "Every act that violates the law and brings harm to others, obliges the person who caused the loss because of his mistake to compensate for the loss." Thus, the elements of unlawful acts (PMH) can be drawn from the contents of the article, namely:

a. There is an Unlawful Acts;

b. There is a mistake;

c. There is a causal relationship between loss and action;

d. there is a loss.

1) There is an element of unlawful acts

Acts against the law can be interpreted that there is an act or action from the perpetrator who violates/against the law. In the past, the notion of breaking the law was interpreted in a narrow perspective, namely only from the side of written law, in this case, the law. So, if a person or legal entity can only be sued if he violates the written law, that is, only those who violate the law.

However, since 1919, there has been a decision by the Dutch Supreme Court in the Arrest CohenLindenbaum case (H.R. 31 January 1919) [12], which then has 
expanded the notion of being against the law not only limited to the law (written law only) but also unwritten law, as follows:

a. Violating the law, meaning that the act committed clearly violates the law.

b. Violating the subjective rights of others, meaning if the actions taken have violated the rights of others which are guaranteed by law (including but not limited to personal rights, freedoms, material rights, honor, good name or other individual rights.

c. Contrary to the legal obligations of the perpetrator, meaning legal obligations, both written and unwritten, including public law.

d. Contrary to decency, namely moral rules (Article 1335 in conjunction with Article 1337 of the Civil Code)

e. Contrary to proper prudence in society. This criterion is based on unwritten law (relative in nature). That is an act that is contrary to a good/proper attitude in society to pay attention to the interests of others.

2) The element of fault

The fault referred to here can be interpreted into 2 (two), which can be caused by intentional or due to negligence. Intentional in question is the awareness that if done by a normal person he will know the consequences or consequences of his actions which of course will harm others. Meanwhile, the negligence in question is an act of ignoring something that should be done, or not being careful or careful so that it causes harm to others [13]. However, sometimes certain circumstances can negate the element of guilt, for example when circumstances force (overmacht) or the perpetrator is mentally unsound (crazy).

3) The element of a causal relationship between loss and action (Causality Relationship)

That is, there is a causal relationship between the actions taken and the consequences that will arise later. It can be exemplified if, the loss incurred/received is caused by the actions of the perpetrator or it can be said, the loss will not occur if the perpetrator does not commit the unlawful act.

4) The element of loss

As a result of the actions of the perpetrators, they cause losses. The losses in question are divided into two, namely material and immaterial. Where material losses, for example, are losses due to car collisions, loss of profits, costs of goods, costs, and others. Meanwhile, immaterial losses are, for example, fear, disappointment, regret, pain, and loss of enthusiasm for life which in practice will be valued in the form of money.
The provision of compensation according to the Civil Code is as follows [13]:

1. Compensation for all unlawful acts (Article 1365 of the Civil Code);

2. Compensation for actions committed by other people (Article 1367 of the Civil Code). Article 1367 paragraph (1) of the Civil Code, a person is not only responsible for losses caused by his own actions, but also for losses caused by the actions of people who are his dependents or caused by goods that are under his control (vicarious liability).

3. Compensation for the owner of the property (Article 1368 of the Civil Code)

4. Compensation for the owner of the collapsed building (Article 1369 of the Civil Code)

5. Compensation for the family left behind by the person killed (Article 1370 of the Civil Code)

6. Compensation due to injuries or limb defects (Article 1371 of the Civil Code)

7. Compensation for acts of humiliation (Article 1372 of the Civil Code)

If analyzed based on the elements of unlawful acts according to Hoffman, as follows [14]:

a. There are elements who do the deed (er moet een daad zjin verricht). It is said that those who commit acts against the law are that apart from the parties, they are also notaries who make the authentic deed, the nominee deed.

b. The element of unlawful acts (die daad moet aan een ander schade heb bentoege bracht). The actions carried out by the parties and the notary are legal smuggling. Where the act is contrary to Article 1365 of the Civil Code, where it violates the provisions of the applicable law and is an unlawful act.

c. Elements of actions that cause harm to others (de daad moet aan een ander schade heb bentoege bracht). The actions of the parties by making a nominee agreement, in the form of an authentic deed, can later harm other parties, namely in this case a third party.

d. The element of action that arises because of an error that can be harmed to him (de daad moet aan schuld zijin te witjen). The act is where the goods or objects that should belong to him are not actually his. For example, in the case of tax evasion. 


\subsection{Legal Consequences for Notary Making Nomina Deeds}

A notary who is a public official who is authorized to make an authentic deed, against unlawful acts committed by the parties in the nominee deed, in the law of the agreement itself has been specifically regulated in Book III of the Civil Code. Where it is regulated regarding the terms of the validity of the agreement in Article 1320 of the Civil Code to Article 1337 of the Civil Code. When viewed from the terms of the agreement above, there is a relationship and the role of a notary in these conditions. The Role of Notaries in Article 1320 of the Civil Code [9] which states the conditions for the validity of an agreement, namely:

a. The existence of an agreement means that if the appearers consisting of the parties who will make the agreement must be those who mutually agreed between the parties when they will appear before a Notary. This implies that the parties who make the agreement have an agreement or there is an adjustment of will and mutual agreement of each other's will which will later be born by the parties without coercion, mistakes, and fraud in the form of a deed.

b. Competence of the Parties, which in this condition clearly shows the role of the Notary. The notary in this condition is required to check the identity of the parties facing him before him and who will sign the deed he has made, through the identification of the parties. This is contained in Article 39 of the Law on Notary Positions, where the identity must match the identification given to the Notary at the time of making the deed and clearly explained in the Deed.

c. A certain thing, namely that the agreement that is felt or made must be about a certain thing which is the subject of the agreement, namely the existence of an object of the agreement. In this case, the role of the Notary is not so obvious, because the object of an agreement is usually in the deed will lie in the contents of the deed. The object of an agreement is free provided that the object of the agreement is not an object prohibited by law. There are other things that regulate the requirements that have been regulated in Article 1332-1334 of the Civil Code, especially if the object of the agreement is in the form of goods.

d. A lawful cause, the cause or basis of the making of a deed must be a lawful cause, which means that the cause or cause is a matter that causes a legal relationship in the form of a series of interests that must be fulfilled as stated and written in the contents of the legal relationship. . The lawful reason is regulated in Articles 1335- 1337 of the Civil Code. In Article 1335 of the Civil Code, it is explained that what is called a lawful cause is: 1 . not without cause 2 . not a fake cause 3 . not a forbidden cause.
A Notary Deed, as an authentic deed is an agreement made by the parties that are binding on the party who made it, therefore the legal requirements of an agreement must be fulfilled (Article 1320 of the Civil Code), as previously explained. The existing contract law regulates certain legal consequences if the conditions of the agreement are valid, where the subjective and objective conditions are not met. If the subjective conditions are not met, then the agreement that has been made can be canceled (vernietigbaar). As long as there is a request by a certain person or interested party. If then the objective conditions cannot be met, then the agreement will be null and void (nietig) [15], without the need for requests from other parties, thus the agreement is considered invalid, never existed, and is not binding on anyone.

Basically, in the making of a notary deed, it is only the submission of clauses that have been agreed upon by the parties, the will of the parties themselves. Based on the authority as a Notary, as stated in Article 15 of the Law on Notary Positions [1] and it is intended for the strength of evidence from a notarial deed, then there are (two) understandings, namely:

a. The task of the position of a Notary is to formulate the wishes/actions of the parties into an authentic deed, taking into account of course the applicable legal rules.

b. A Notary Deed as an authentic deed has perfect evidentiary power, so it does not need to be proven or supplemented with other evidence if there are people/parties who judge or state that the deed is not true.

Even though the Notary only follows the will of the Notary parties, however, there are also prohibitions and it is not the authority of the Notary to make a deed, namely Article 52 paragraph (1) and Article 53 of the Notary Position Act, stating that in certain circumstances the Notary is prohibited from making a deed [1]. This prohibition only exists and applies to legal subjects, namely the appearers, where if the legal subjects are prohibited. So, with the substance of the deed (deed), anything is not allowed to be made.

Duties and obligations that are based on a legitimate authority are regulated in written regulations, both those that come from the law or an agreement, of course, there will be a consequence, in a cause of action or authority there is a deed that will arise. Notary, a public official who is given the authority to make an authentic deed. Because the notary concerned has the authority and is obliged to fulfill all the requirements that have been determined, then the deed he made, a violation or deviation will result in the deed made by the notary also be invalid. 
If the deed made by a notary, in this case, the nominee's deed, is detrimental to another party, the notary can also be sued civilly to the District Court and even a notary can be criminally prosecuted as a result of the act or make a deed which is an unlawful act. Where this nominee deed is said to be legal smuggling [16]. As a result of a notary making a prohibited agreement.

Likewise, there is a regulation in Article 33 paragraph (1) of Law Number 25 of 2007 concerning Investment [3]. Where this violates the Nationality Principle contained in the Basic Agrarian Law Number 5 of 1960. So, a notary has finally violated 2 (two) regulations, namely the Law on Notary Positions Number 30 of 2004 Jo. Law Number 2 of 20014 concerning the Position of Notary [1] as well as regulations regarding the Notary Code of Ethics can be emphasized as follows:

(1) Before carrying out his/her position, a Notary is obliged to take an oath/promise according to his/her religion in front of the Minister or appointed official.

(2) The oath/promise as referred to in paragraph (1) reads as follows:

"I swear/promise:

that I will obey and be loyal to the Republic of Indonesia, Pancasila, and the 1945 Constitution of the Republic of Indonesia, the Law on Notary Positions, and other laws and regulations.

that I will carry out my position in a trustworthy, honest, thorough, independent, and impartial manner.

that I will maintain my attitude, behavior, and will carry out my obligations accordingly

with the code of professional ethics, honor, dignity, and my responsibilities as a Notary.

that I will keep the contents of the deed and information obtained in the exercise of my position confidential.

that I can be appointed to this position, either directly or indirectly, under any name or pretext, never and will not give or promise anything to anyone."

The Honorary Council of the Indonesian Notary Association can also impose sanctions [17] for a notary who commits an unlawful act, as stated in Article 6 paragraph (1) of the Notary Code of Ethics. A Notary as public officials is required to work professionally by mastering the intricacies of their profession. In carrying out their duties, notaries must be aware of their obligations to work independently, honestly, impartially, and full of responsibility and professionalism.
If a notary continues to make a nominee deed containing an unlawful act, it will result in the agreement and/or statement being declared null and void. As a notary, you must also understand these prohibitions so that in the future it will not harm other parties or the notary himself.

\section{CONCLUSION}

In closing, based on what has been discussed previously, the authors draw the following conclusions: A notary is given the authority as a public official to make an authentic deed, so he must also know what will be the consequences of the authentic deed he made if the deed is authentic. a deed that is an unlawful act. So, from the beginning, the deed became null and void and was an invalid deed. On the other hand, if the deed is made, it will harm other parties by the Notary's actions outside the authority, so that it can result in the Notary himself either from the result of civil claims through compensation or criminally with criminal charges or even administrative consequences that will be subject to sanctions. administrative duties can even lead to the dismissal of a notary position in a dishonorable manner.

\section{ACKNOWLEDGMENT}

The authors would like to thank the Faculty of Social Sciences and Law for facilitating this activity so that the authors get many benefits for scientific development.

\section{REFERENCES}

[1] Republik Indonesia, Undang-Undang Nomor 2 Tahun 2014 Tentang Perubahan Atas UndangUndang Nomor 30 Tahun 2004 Tentang Jabatan Notaris. Indonesia, 2014.

[2] B. Harsono, Hukum Agraria Indonesia, Sejarah Pembentukan Undang-Undang Pokok Agraria, Isi Dan Pelaksanaannya. Jakarta: Djambatan, 2007.

[3] D. P. R. R. Indonesia, "Undang Undang Republik Indonesia Nomor 25 Tahun 2007," Jundang Undang Republik Indones. Nomor 25 Tahun 2007 Tentang Penanaman Modal, 2007.

[4] P. M. Marzuki, Penelitian Hukum. Jakarta: Prenada Media Group, 2016. 
[5] S. Mertokusumo, Penemuan Hukum Sebuah Pengantar. Yogyakarta: Liberty, 2007.

[6] A. H. Wijaya, "NOMINEE DALAM SAHAM TERKAIT KEBIJAKAN PENGAMPUNAN PAJAK, $\quad$ Notaire, 2019, doi: 10.20473/ntr.v1i2.9937.

[7] B. A. Garner, Black's Law Dictionary. Amerika: west, 2009.

[8] KUH Perdata, Article 1365 of the Civil Code (Kuhperdata).

[9] I. D. A. D. Jastrawan and I. N. Suyatna, "Keabsahan Perjanjian Pinjam Nama (Nominee) Oleh Warga Negara Asing Dalam Penguasaan Hak Milik Atas Tanah Di Indonesia," Kertha Semaya J. Ilmu Huk., 2019, doi: 10.24843/km.2019.v07.i02.p13.

[10] Komari, "Mahkamah Agung Republik Indonesia," Mahkamah Agung Republik Indones., 2015.

[11] A. F. Rasyidi, "Legalitas Penyidik Sebagai Saksi Dalam Pemeriksaan Persidangan Tindak Pidana Narkotika (Analisis Pertimbangan Hakim Dalam Putusan Mahkamah Agung Nomor: 454 K/PID.SUS/2011, 1531

K/PID.SUS/2010, DAN 2588 K/PID.SUS/2010)," J. Penelit. Huk. Jure, 2017, doi: 10.30641/dejure 2016.v16.353-369.

[12] M. Fuady, Peerbuatan Melawan Hukum. Bandung: Citra Aditya Bakti, 2002.

[13] S. Prayogo, "Penerapan Batas-Batas Wanprestasi Dan Perbuatan Melawan Hukum Dalam Perjanjian," J. Pembaharuan Huk., vol. 3, no. 2, p. 280, 2016, doi: 10.26532/jph.v3i2.1453.
[14] N. S. Indiraharti, "Aspek Keabsahan Perjanjian Dalam Hukum Kontrak (Suatu Perbandingan Antara Indonesia Dan Korea Selatan)," J. Huk. PRIORIS, 2014.

[15] D. Haspada, "Perjanjian Nominee Antara Warga Negara Asing dengan Warga Negara Indonesia dalam Praktik Jual Beli Tanah Hak Milik yang Dihubungkan dengan Pasal 1313 Kitab UndangUndang Hukum Perdata," Wacana Paramarta J. Ilmu Huk., 2018, doi: 10.32816/paramarta.v17i2.77.

[16] N. KUNTJORO, "Efektivitas Pengawasan Majelis Pengawas Daerah (MPD) Kota Yogyakarta Terhadap Perilaku Notaris di Kota Yogyakarta menurut Kode Etik Notaris," J. Lex Renaiss., 2016, doi: 10.20885/jlr.vol1.iss2.art5.

[17] Ikatan Notaris Indonesia, Kode Etik Notaris Indonesia. 2005. 